\title{
A TAXONOMIC SCHEME FOR AEROBIC DIPHTHEROIDS FROM HUMAN SKIN
}

\author{
DOROTHY A. SOMERVILLE* \\ Department of Bacteriology, St John's Hospital for Diseases of the Skin, \\ Homerton Grove, London E9 6BX
}

AEROBIC diphtheroids are commonly found in large numbers on the skin, especially of adults in whom they, with the coagulase-negative staphylococci and micrococci, are predominant members of the resident normal flora (Marples, 1965; Somerville, 1969). Diphtheroids have varied biochemical properties, and many are capable of breaking down the lipids of sebum to produce free fatty acids (Reisner et al., 1968; Smith and Willett, 1968). In fact, the prevalence of diphtheroids on the skin appears to be controlled to some extent by the presence of sebum (Somerville, 1969; Puhvel and Reisner, 1970), and they in their turn may exert some control on the rest of the skin microflora (Marples and Williamson, 1969; Smith, 1969b). Despite considerable investigation, work on the ecology of the cutaneous diphtheroids has been made difficult by the lack of a suitable taxonomic scheme.

Most workers agree that the standard classification for the genus Corynebacterium (Breed, Murray and Smith, 1957) is not useful for skin diphtheroids. These organisms are extremely varied in cellular appearance, colonial morphology, and biochemical characteristics. Several grouping schemes have been proposed (Evans, 1968; Marples, 1969; Smith, 1969a; Somerville, 1970) in which properties such as sugar fermentation, nitrate reduction, lipase activity, lipophilia, and urease production are used. Marples (1969) suggested that the last three characters were closely linked to the activity of the organisms in vivo and are therefore more applicable than other characters to a classification scheme. However, none of the proposed schemes proved satisfactory when used for the study of large numbers of strains, because in each case only a small proportion of the strains could be classified.

Evans, applying her pilot grouping scheme, found differences in the distribution of the various aerobic cutaneous diphtheroids over the body surface. For the present study I decided to use a similar but more comprehensive range of tests to obtain an ecological grouping of diphtheroids from the skin. In any taxonomic scheme that is to be useful in studies of ecology or epidemiology, the tests must be simple and readily applicable to large numbers of strains. Diphtheroids isolated from healthy young adults were studied in an attempt to produce a workable scheme that fulfilled these criteria.

\footnotetext{
Received 28 July 1972; accepted 23 Oct. 1972.

* Present address: Department of Bacteriology, Royal Infirmary, Glasgow C4. 


\section{MATERIALS AND METHODS}

\section{Organisms}

The skin of healthy young adults attending colleges of education was rubbed with sterile cotton-wool swabs moistened in nutrient broth. Sites sampled were the nose, chest, periumbilical area, groin, thigh, shin, shoulder, lumbar region of the back, cheek, forehead, forearm, axilla, and fourth toe-web. All the swabs were seeded on to Oxoid Blood Agar Base containing 5 per cent. horse blood, and the plates were incubated aerobically at $37^{\circ} \mathrm{C}$ for $48 \mathrm{hr}$. Organisms isolated were grouped as Micrococcaceae, aerobic diphtheroids, other Gram-positive bacilli, intestinal organisms, " mimeae ", and other Gram-negative organisms; representative types of the diphtheroid organisms were subcultured on blood agar for other tests. No attempt was made to isolate obligate anaerobic diphtheroids ("Corynebacterium acnes").

TABLE I

Corynebacterium reference strains used in the study

\begin{tabular}{|c|c|c|}
\hline Species & NCTC number & $\begin{array}{l}\text { Group in } \\
\text { proposed scheme }\end{array}$ \\
\hline $\begin{array}{l}\text { C. bovis } \\
\text { C. minutissimum } \\
\text { C. ulcerans } \\
\text { C. xerosis } \\
\text { C. pseudotuberculosis } \\
\text { C. renale } \\
\text { C. striatum (flavidum) } \\
\text { C. haemolyticum } \\
\text { C. hofmanii } \\
\text { (pseudodiphtheriticum) }\end{array}$ & $\begin{array}{r}3224 \\
10288 \\
7910 \\
7243 \\
3450 \\
7448 \\
764 \\
8452 \\
231\end{array}$ & $\begin{array}{l}2 \\
2 \\
3 \\
4 \\
5 \\
6 \\
\text { IV } \\
\text { V } \\
\text { VIII }\end{array}$ \\
\hline C. murium & 949 & VIII \\
\hline
\end{tabular}

In all, 1381 strains of aerobic cutaneous diphtheroids isolated from the students and 120 fluorescent strains obtained from the skin of psychiatric patients in another investigation were examined for 22 characteristics. Reference strains were obtained from the National Collection of Type Cultures (table I) and tested similarly. Another 1665 strains of diphtheroids, some from the skin of healthy persons and others from patients with skin diseases, were later classified according to the proposed scheme.

All isolates were stained by Gram's and Albert's methods and examined for cellular morphology and the presence of metachromatic granules. Seeding of all the test media was made from a 36-hr peptone-water culture. Stock cultures were maintained on serum-agar slopes stored at $4^{\circ} \mathrm{C}$.

\section{Growth studies}

Each isolate was seeded on to nutrient agar (Oxoid Blood Agar Base), and nutrient agar with the addition of 1 per cent. Tween 80 and incubated for $48 \mathrm{hr}$ at $37^{\circ} \mathrm{C}$. Growth was assessed as none, slight, moderate, or heavy on each medium; lipophilic strains were those that showed an obviously increased colonial size on Tween-80 medium, from around $0.5 \mathrm{~mm}$ in diameter on nutrient agar to $2 \mathrm{~mm}$ or more on Tween agar. Strains that showed only slight lipophilic stimulation were recorded as negative in this respect.

Strains were grown on 5 per cent. horse blood agar to determine haemolysis, but this was not found to be a useful characteristic. Pigment production on this medium was noted after 72 hr.

The ability to grow on media containing different Tweens (Marples, 1969) was determined 
for 177 strains. The basal media used were Oxoid Blood Agar Base and Tween agar (Harrigan and McCance, 1966) to which were added 1 per cent. Tween 20,40,60, or 80; growths on the media were assessed as indicated above. These strains were also seeded on to Hoyle's tellurite medium.

Lipolytic activity was indicated by the appearance of a precipitate around the colonies after incubation for $72 \mathrm{hr}$ at $37^{\circ} \mathrm{C}$ on the Tween agars.

All isolates were inoculated on Tissue Culture Medium no. 199 (Wellcome) without antibiotics, sodium bicarbonate, or indicator but with the addition of 2 per cent. agar and 20 per cent. calf serum. They were examined for porphyrin production, shown by coral-red fluorescence under Wood's ultraviolet light, after incubation at $37^{\circ} \mathrm{C}$ for 18 and $36 \mathrm{hr}$.

\section{Biochemical tests}

All biochemical tests were performed as described by Cowan and Steel (1955) and were read after incubation for $1 \mathrm{wk}$ at $37^{\circ} \mathrm{C}$. The production of acid from carbohydrates was tested in Hiss's serum water with 20 per cent. serum and 1 per cent. of the appropriate carbohydrate. Initially, the substrates tested were glucose, lactose, maltose, sucrose, fructose, galactose, mannose, dextrin, inulin, salicin, and starch. After more than 200 strains had been studied, no advantage was seen in continuing to use lactose, dextrin, inulin, salicin, and starch, because few strains attacked them; they were then omitted. Urease production, nitrate reduction, production of indole and acetoin, and methyl-red tests were also included. Catalase and oxidase production were tested but were not included in the classification scheme.

\section{Lipid requirement}

To determine lipid requirement, nutrient agar (Oxoid Blood Agar Base) was extracted three times each with chloroform and ether, and 106 lipophilic strains were inoculated on this lipid-free medium with and without added 0.5 per cent. Tween 80 . Smith (1969a) restricted his study to lipophilic diphtheroids that were lipid dependent, i.e., would not grow on lipid-free media, but of our strains, only four did not grow on the lipid-free medium. It was possible that lipid-dependent diphtheroids had not been isolated from the skin by the culture techniques used in this study. However, counts of organisms isolated from 25 skin areas and grown on media with and without added Tween, indicated that as many aerobic organisms were isolated on blood agar as on oleate-containing media.

\section{Results}

The isolates were all pleomorphic, catalase-positive, non-motile, nonsporing, Gram-positive rods. Generally they produced metachromatic granules, but there was great variation in the number depending to some extent on the conditions of culture. The cells were arranged in palisade formation; they varied from short cocco-bacilli to longer bacillary forms, some straight, some club-shaped. Cellular and colonial morphology varied according to the conditions of growth; these properties were therefore not used in the grouping scheme.

Colonies on blood agar ranged from pinpoint and grey to large, rough, and granular; not all diphtheroids with colonies less than $1 \mathrm{~mm}$ diameter on nutrient agar were lipophilic and only 4 per cent. of the lipophilic strains were lipid dependent. The results obtained in the remaining tests were variable, and the 1501 strains could be arranged into 15 groups, eight for the nonfluorescent strains and seven for the fluorescent strains (figure). The scheme for the fluorescent diphtheroids previously reported (Somerville, 1970) was 
modified slightly by eliminating group 8 and the subdivisions of groups $2,3,4$ and 5. None of the fluorescent diphtheroids included in the present report came from areas of the skin that showed either scaling or fluorescence. Fluorescent isolates from healthy skin areas in subjects suffering from erythrasma at some other site were also excluded.

Results for the non-fluorescent groups are shown in table II. Groups I to VII attacked carbohydrates; groups I to III were lipophilic, group I reduced nitrate; group II was separated from group III by the breakdown of fructose.

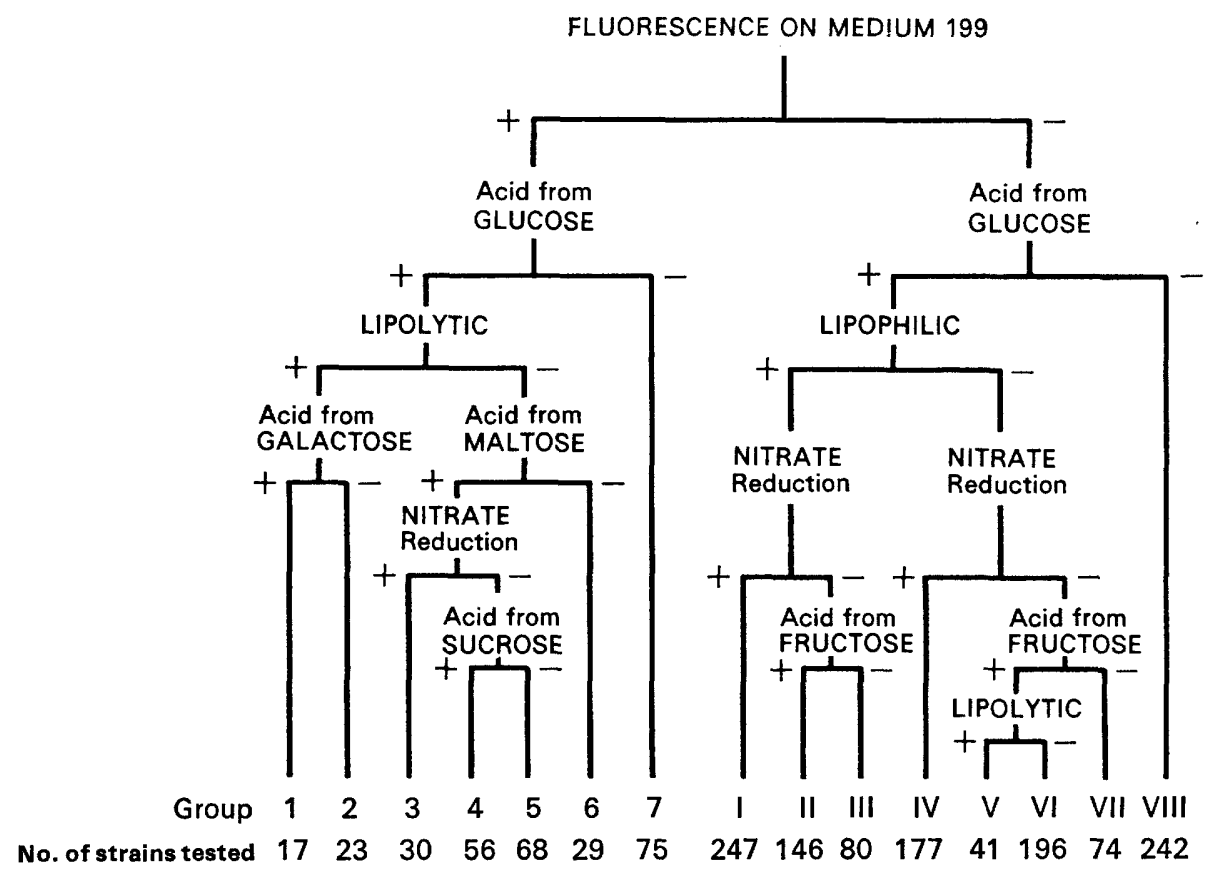

FIGURE.-Key to the identification and grouping of aerobic cutaneous diphtheroids. $+=$ Test positive; $-=$ test negative.

Fructose was chosen from a range of sugars because isolates producing acid from it were more active in other biochemical tests than those not attacking fructose. Groups V, VI and VII were separated from each other by activity on fructose and lipolytic ability. Organisms in group VIII did not produce acid from carbohydrates and in general were biochemically inactive.

The 177 non-fluorescent strains on which additional tests were performed (table III) showed variable ability to grow on and decompose the various Tweens; only 47 ( 27 per cent.) could be fitted into the scheme proposed by Marples (1969). On Hoyle's tellurite medium, 107 strains (60 per cent.) grew, producing either small black colonies or grey colonies of various sizes.

The 1501 strains included in this study had been isolated from various skin sites, and table IV shows the characteristics and distribution of these organisms on human skin. Lipophilic strains were most commonly isolated from the nostrils, axillae, groins, and toe-webs; lipolytic strains were found in all areas, 
mostly in the groin, least often in the nostrils. Fermentative isolates were common in all the areas sampled and strains that reduced nitrate were most common in the nostrils and on the neighbouring areas, such as the forehead and cheek.

The skin distribution of the groups of non-fluorescent diphtheroids is shown in table V. Group I was most commonly isolated from the nostrils. Although

TABLE II

Results of tests on 1203 cutaneous non-fluorescent aerobic diphtheroids

\begin{tabular}{|c|c|c|c|c|c|c|c|c|}
\hline \multirow[b]{2}{*}{ Test } & \multicolumn{8}{|c|}{ Percentage* of strains positive in group } \\
\hline & I & II & III & IV & $\mathrm{V}$ & VI & VII & VIII \\
\hline $\begin{array}{l}\text { Growth on nutrient agar } \\
\text { Metachromatic granules }\end{array}$ & + & $\begin{array}{l}+ \\
+\end{array}$ & $\begin{array}{l}+ \\
+\end{array}$ & + & + & + & $\stackrel{t}{t}$ & $\begin{array}{l}+ \\
+\end{array}$ \\
\hline $\begin{array}{l}\text { Lipophilic } \\
\text { Lipolytic }\end{array}$ & \pm & \pm & $\stackrel{+}{d}$ & $\overline{-}$ & $\bar{t}$ & - & $\begin{array}{l}- \\
-\end{array}$ & - \\
\hline $\begin{aligned} & \text { Acid from: } \text { glucose } \\
& \text { maltose } \\
& \text { sucrose } \\
& \text { fructose } \\
& \text { galactose } \\
& \text { mannose }\end{aligned}$ & $\begin{array}{l}+ \\
+ \\
+ \\
+ \\
+\end{array}$ & $\begin{array}{l}+ \\
\mathrm{d} \\
\mathrm{d} \\
+ \\
+\end{array}$ & $\begin{array}{l}+ \\
d \\
d \\
\frac{d}{d}\end{array}$ & $\begin{array}{l}+ \\
+ \\
+ \\
\frac{d}{d}\end{array}$ & $\begin{array}{l}+ \\
+ \\
\mathrm{d} \\
+ \\
+ \\
+\end{array}$ & $\begin{array}{l}+ \\
+ \\
d \\
+ \\
+\end{array}$ & $\begin{array}{l}+ \\
\mathrm{d} \\
\mathrm{d} \\
- \\
-\end{array}$ & $\begin{array}{l}\bar{z} \\
= \\
= \\
=\end{array}$ \\
\hline $\begin{array}{l}\text { Nitrate reduction } \\
\text { Methyl red } \\
\text { Voges Proskauer } \\
\text { Indole production }\end{array}$ & $\begin{array}{l} \pm \\
- \\
-\end{array}$ & $\begin{array}{l}- \\
\overline{-}\end{array}$ & $\begin{array}{l}\bar{z} \\
\bar{z}\end{array}$ & $\begin{array}{l}+ \\
\mathrm{d} \\
-\end{array}$ & $\frac{\bar{d}}{\overline{-}}$ & $\underline{\bar{d}}$ & $\begin{array}{l}- \\
\bar{z} \\
-\end{array}$ & $\begin{array}{l}\frac{d}{-} \\
-\end{array}$ \\
\hline Urease & - & - & - & - & - & - & - & d \\
\hline Number in group & 247 & 146 & 80 & 177 & 41 & 196 & 74 & 242 \\
\hline
\end{tabular}

$*+=80-100$ per cent. of strains positive. $d=21-79$ per cent. of strains positive. $-=0-20$ per cent. of strains positive or 80-100 per cent. of strains negative.

none of the other groups predominated in such a marked way on the other sites sampled, the commonest group in the groin was group II, in the axillae and toe-webs groups II and III, on the forehead, cheek, shoulder, and back groups IV, VI, and VIII, and on the other sites groups VI and VIII. Group IV was commonest at sites where there is much skin lipid, i.e., forehead, cheeks, shoulder, and back, but in fact none of these strains showed lipophilic properties in vitro.

The skin distribution of the 298 fluorescent isolates is shown in table VI.

During and after this study the proposed grouping scheme was used to investigate additional strains of aerobic cutaneous diphtheroids, including isolates from patients with erythrasma and trichomycosis axillaris as well as from healthy skin. Altogether 3166 strains have been grouped into the 15 categories as shown in table VII. 
It was possible to group the reference strains according to this scheme (table I); C. hofmannii (pseudodiphtheriticum) (NCTC no. 231) and C. murium (NCTC no. 949) fall into group VIII, the non-fluorescing, non-fermentative group. C. xerosis (NCTC no. 7243) was not lipophilic and did not reduce

TABLE III

Results of additional tests performed on 177 strains of non-fluorescent aerobic diphtheroids

\begin{tabular}{|c|c|c|c|c|c|c|c|c|c|}
\hline \multirow[b]{2}{*}{ Test } & \multicolumn{9}{|c|}{ Number of strains giving positive result in group } \\
\hline & $\mathbf{I}$ & II & III & IV & $\mathrm{V}$ & $\mathrm{VI}$ & VII & VIII & Total \\
\hline $\begin{array}{l}\text { Growth on Tween-agar base } \\
\text { Growth on Tween-agar base }+ \text { Tween } 20 \\
\text { Growth on Tween-agar base }+ \text { Tween } 40 \\
\text { Growth on Tween-agar base }+ \text { Tween } 60 \\
\text { Growth on Tween-agar base }+ \text { Tween } 80\end{array}$ & $\begin{array}{l}27 \\
24 \\
13 \\
14 \\
28\end{array}$ & $\begin{array}{l}19 \\
16 \\
10 \\
10 \\
18\end{array}$ & $\begin{array}{l}17 \\
15 \\
11 \\
10 \\
16\end{array}$ & $\begin{array}{l}25 \\
16 \\
18 \\
15 \\
24\end{array}$ & $\begin{array}{r}10 \\
9 \\
8 \\
6 \\
10\end{array}$ & $\begin{array}{l}27 \\
23 \\
20 \\
19 \\
27\end{array}$ & $\begin{array}{l}7 \\
3 \\
6 \\
6 \\
7\end{array}$ & $\begin{array}{l}38 \\
33 \\
25 \\
20 \\
33\end{array}$ & $\begin{array}{l}170 \\
129 \\
111 \\
100 \\
163\end{array}$ \\
\hline $\begin{array}{l}\text { Growth on nutrient agar } \\
\text { Growth on nutrient agar + Tween } 20 \\
\text { Growth on nutrient agar + Tween } 40 \\
\text { Growth on nutrient agar + Tween } 60 \\
\text { Growth on nutrient agar + Tween } 80\end{array}$ & $\begin{array}{l}29 \\
26 \\
23 \\
14 \\
29\end{array}$ & $\begin{array}{l}21 \\
16 \\
11 \\
18 \\
21\end{array}$ & $\begin{array}{l}17 \\
15 \\
15 \\
13 \\
17\end{array}$ & $\begin{array}{l}25 \\
21 \\
18 \\
17 \\
24\end{array}$ & $\begin{array}{r}10 \\
9 \\
8 \\
9 \\
10\end{array}$ & $\begin{array}{l}27 \\
23 \\
23 \\
22 \\
26\end{array}$ & $\begin{array}{l}7 \\
5 \\
6 \\
6 \\
7\end{array}$ & $\begin{array}{l}41 \\
28 \\
31 \\
26 \\
40\end{array}$ & $\begin{array}{l}177 \\
143 \\
135 \\
115 \\
174\end{array}$ \\
\hline $\begin{array}{l}\text { Lipophilic: Tween } 20 \\
\text { Lipophilic: Tween } 40 \\
\text { Lipophilic: Tween } 60 \\
\text { Lipophilic: Tween } 80\end{array}$ & $\begin{array}{r}19 \\
0 \\
1 \\
29\end{array}$ & $\begin{array}{r}10 \\
1 \\
0 \\
21\end{array}$ & $\begin{array}{r}11 \\
0 \\
0 \\
17\end{array}$ & $\begin{array}{l}0 \\
0 \\
0 \\
0\end{array}$ & $\begin{array}{l}0 \\
0 \\
0 \\
0\end{array}$ & $\begin{array}{l}0 \\
0 \\
0 \\
0\end{array}$ & $\begin{array}{l}0 \\
0 \\
0 \\
0\end{array}$ & $\begin{array}{l}3 \\
0 \\
0 \\
6\end{array}$ & $\begin{array}{r}43 \\
1 \\
1 \\
73\end{array}$ \\
\hline $\begin{array}{l}\text { Lipolytic: Tween } 20 \\
\text { Lipolytic: Tween } 40 \\
\text { Lipolytic: Tween } 60 \\
\text { Lipolytic: Tween } 80\end{array}$ & $\begin{array}{l}28 \\
13 \\
12 \\
19\end{array}$ & $\begin{array}{l}17 \\
10 \\
11 \\
14\end{array}$ & $\begin{array}{l}16 \\
12 \\
11 \\
14\end{array}$ & $\begin{array}{r}10 \\
10 \\
7 \\
8\end{array}$ & $\begin{array}{r}9 \\
9 \\
8 \\
10\end{array}$ & $\begin{array}{l}6 \\
8 \\
5 \\
0\end{array}$ & $\begin{array}{l}2 \\
4 \\
4 \\
1\end{array}$ & $\begin{array}{l}22 \\
24 \\
17 \\
20\end{array}$ & $\begin{array}{r}110 \\
90 \\
75 \\
96\end{array}$ \\
\hline Inhibited by Tween & 7 & 1 & 0 & 4 & 4 & 5 & 1 & 11 & 33 \\
\hline Growth on tellurite & 17 & 11 & 15 & 14 & 9 & 11 & 3 & 27 & 107 \\
\hline $\begin{aligned} & \text { Acid from: } \text { lactose } \\
& \text { dextrin } \\
& \text { salicin } \\
& \text { insulin } \\
& \text { starch }\end{aligned}$ & $\begin{array}{l}0 \\
0 \\
0 \\
1 \\
0\end{array}$ & $\begin{array}{l}0 \\
3 \\
1 \\
0 \\
0\end{array}$ & $\begin{array}{l}0 \\
1 \\
0 \\
0 \\
0\end{array}$ & $\begin{array}{l}0 \\
3 \\
0 \\
0 \\
0\end{array}$ & $\begin{array}{l}0 \\
0 \\
0 \\
0 \\
0\end{array}$ & $\begin{array}{l}0 \\
1 \\
0 \\
0 \\
0\end{array}$ & $\begin{array}{l}0 \\
0 \\
0 \\
0 \\
1\end{array}$ & $\begin{array}{l}0 \\
0 \\
0 \\
0 \\
0\end{array}$ & $\begin{array}{l}0 \\
7 \\
1 \\
1 \\
1\end{array}$ \\
\hline Number in group & 29 & 21 & 17 & 25 & 10 & 27 & 7 & 41 & 177 \\
\hline
\end{tabular}

nitrate, although Smith (1969a) found that the three reference strains of C. xerosis (ATCC strains) he studied all reduced nitrate; C. striatum (NCTC no. 764) did reduce nitrate and Smith could differentiate between these two species only by sugar fermentation. However, in this study, C. xerosis produced porphyrins while C. striatum did not. C. bovis (NCTA no. 3224) was placed in the same group as C. minutissimum (NCTC no. 10288). Breed et al. (1957) state that $C$. bovis does not decompose carbohydrates though Smith (1969a) found that three reference strains produced acid from glucose, fructose, and galactose 
and one did so from maltose. $C$. minutissimum and $C$. bovis could be differentiated by other tests, for example sucrose fermentation and urease produc-

TABLE IV

Incidence and characteristics of diphtheroids isolated from various skin sites

\begin{tabular}{|c|c|c|c|c|c|c|}
\hline \multirow[b]{2}{*}{ Source } & \multirow{2}{*}{$\begin{array}{l}\text { Number of } \\
\text { strains } \\
\text { examined }\end{array}$} & \multicolumn{5}{|c|}{ Percentage of strains showing indicated charąteristic } \\
\hline & & Fluorescent & Lipophilic & Lipolytic & Fermentative & $\begin{array}{l}\text { Nitrate } \\
\text { reducing }\end{array}$ \\
\hline $\begin{array}{l}\text { Nose } \\
\text { Axillae } \\
\text { Groins } \\
\text { Toe-webs } \\
\text { Forehead } \\
\text { Cheek } \\
\text { Shoulder } \\
\text { Lumbar back } \\
\text { Forearm } \\
\text { Chest } \\
\text { Periumbilical area } \\
\text { Thigh } \\
\text { Shin }\end{array}$ & $\begin{array}{r}277 \\
127 \\
236 \\
170 \\
49 \\
49 \\
71 \\
120 \\
80 \\
74 \\
78 \\
85 \\
85\end{array}$ & $\begin{array}{r}0 \\
63 \\
51 \\
36 \\
4 \\
0 \\
11 \\
5 \\
6 \\
8 \\
5 \\
1 \\
5\end{array}$ & $\begin{array}{l}69 \\
34 \\
32 \\
34 \\
24 \\
37 \\
11 \\
24 \\
30 \\
23 \\
28 \\
24 \\
25\end{array}$ & $\begin{array}{r}6 \\
13 \\
22 \\
12 \\
16 \\
16 \\
11 \\
18 \\
14 \\
8 \\
24 \\
20 \\
25\end{array}$ & $\begin{array}{l}83 \\
84 \\
79 \\
75 \\
88 \\
86 \\
69 \\
77 \\
74 \\
74 \\
71 \\
72 \\
79\end{array}$ & $\begin{array}{l}88 \\
17 \\
20 \\
25 \\
35 \\
39 \\
27 \\
29 \\
21 \\
22 \\
31 \\
13 \\
19\end{array}$ \\
\hline Any & 1501 & 20 & 36 & 15 & 78 & 35 \\
\hline
\end{tabular}

TABLE V

Distribution of non-fluorescent diphtheroids in different areas

\begin{tabular}{|c|c|c|c|c|c|c|c|c|c|}
\hline \multirow[b]{2}{*}{ Source } & \multirow{2}{*}{$\begin{array}{l}\text { Number of } \\
\text { strains } \\
\text { examined }\end{array}$} & \multicolumn{8}{|c|}{ Percentage of strains in group } \\
\hline & & $\mathbf{I}$ & II & III & IV & $\mathrm{V}$ & VI & VII & VIII \\
\hline $\begin{array}{l}\text { Nose } \\
\text { Axillae } \\
\text { Groins } \\
\text { Toe-webs } \\
\text { Forehead } \\
\text { Cheek } \\
\text { Shoulder } \\
\text { Lumbar back } \\
\text { Forearm } \\
\text { Chest } \\
\text { Periumbilical area } \\
\text { Thigh } \\
\text { Shin }\end{array}$ & $\begin{array}{r}277 \\
47 \\
116 \\
108 \\
47 \\
49 \\
63 \\
114 \\
75 \\
68 \\
74 \\
84 \\
81\end{array}$ & $\begin{array}{r}62 \\
11 \\
10 \\
6 \\
13 \\
16 \\
5 \\
8 \\
9 \\
9 \\
12 \\
1 \\
4\end{array}$ & $\begin{array}{r}5 \\
30 \\
28 \\
26 \\
6 \\
10 \\
5 \\
9 \\
15 \\
9 \\
8 \\
10 \\
6\end{array}$ & $\begin{array}{r}2 \\
21 \\
10 \\
16 \\
6 \\
6 \\
2 \\
6 \\
1 \\
1 \\
4 \\
11 \\
11\end{array}$ & $\begin{array}{r}13 \\
11 \\
10 \\
19 \\
23 \\
21 \\
22 \\
21 \\
8 \\
13 \\
12 \\
11 \\
15\end{array}$ & $\begin{array}{r}\cdots \\
2 \\
4 \\
5 \\
9 \\
4 \\
2 \\
6 \\
3 \\
1 \\
8 \\
4 \\
5\end{array}$ & $\begin{array}{r}1 \\
15 \\
17 \\
6 \\
28 \\
21 \\
27 \\
18 \\
30 \\
30 \\
16 \\
30 \\
23\end{array}$ & $\begin{array}{r}\dddot{2} \\
2 \\
5 \\
4 \\
2 \\
8 \\
13 \\
10 \\
8 \\
10 \\
9 \\
7 \\
16\end{array}$ & $\begin{array}{r}17 \\
9 \\
16 \\
19 \\
13 \\
14 \\
25 \\
22 \\
27 \\
26 \\
30 \\
27 \\
20\end{array}$ \\
\hline All & 1203 & 21 & 12 & 7 & 15 & 3 & 16 & 6 & 20 \\
\hline
\end{tabular}

Bold numbers indicate areas where group is significantly more common than at other sites.

tion, which did not appear in the proposed dichotomous grouping scheme. Rather more of the reference strains produced porphyrins than was expected. C.xerosis, C. bovis, C. pseudotuberculosis, C. ulcerans, and C. renale, in addition to $C$. minutissimum, showed the typical coral-red fluorescence on 199 medium when grown under the given conditions. This confirms the varied biochemical 
activities found amongst the fluorescent diphtheroids and emphasises the finding that more than one species produces porphyrins (McBride, Montes and Knox,

TABLE VI

Distribution of fluorescent diphtheroids on different areas

\begin{tabular}{|c|c|c|c|c|c|c|c|c|}
\hline \multirow[b]{2}{*}{ Site } & \multirow{2}{*}{$\begin{array}{l}\text { Number of } \\
\text { strains } \\
\text { examined }\end{array}$} & \multicolumn{7}{|c|}{ Percentage of strains in group } \\
\hline & & 1 & 2 & 3 & 4 & 5 & 6 & 7 \\
\hline $\begin{array}{l}\text { Axillae } \\
\text { Groins } \\
\text { Toe-webs } \\
\text { Elsewhere }\end{array}$ & $\begin{array}{r}80 \\
120 \\
62 \\
36\end{array}$ & $\begin{array}{r}3 \\
8 \\
0 \\
14\end{array}$ & $\begin{array}{r}4 \\
12 \\
3 \\
11\end{array}$ & $\begin{array}{r}10 \\
10 \\
13 \\
6\end{array}$ & $\begin{array}{r}9 \\
27 \\
24 \\
6\end{array}$ & $\begin{array}{l}35 \\
14 \\
26 \\
19\end{array}$ & $\begin{array}{r}20 \\
4 \\
13 \\
0\end{array}$ & $\begin{array}{l}20 \\
25 \\
21 \\
44\end{array}$ \\
\hline Any & 298 & 6 & 8 & 10 & 19 & 23 & 10 & 25 \\
\hline
\end{tabular}

Bold numbers indicate areas where group is significantly more common than at other sites.

1970; Somerville, 1970). All groups of fluorescent diphtheroids have been isolated from lesions of erythrasma (Somerville, 1970; Somerville et al., 1970) which is the result of an overgrowth of diphtheroid members of the normal skin flora (Somerville, 1972).

TABLE VII

Distribution of different groups in all the strains studied

\begin{tabular}{l|cc}
\hline \multicolumn{1}{c|}{ Group } & $\begin{array}{c}\text { Number of } \\
\text { strains examined }\end{array}$ & $\begin{array}{c}\text { Percentage } \\
\text { of total }\end{array}$ \\
\hline Fluorescent group 1 & 119 & 4 \\
Fluorescent group 2 & 220 & 7 \\
Fluorescent group 3 & 98 & 3 \\
Fluorescent group 4 & 280 & 9 \\
Fluorescent group 5 & 387 & 12 \\
Fluorescent group 6 & 88 & 3 \\
Fluorescent group 7 & 385 & 12 \\
Non-fluorescent group I & 254 & 8 \\
Non-fluorescent group II & 162 & 5 \\
Non-fluorescent group III & 87 & 3 \\
Non-fluorescent group IV & 217 & 7 \\
Non-fluorescent group V & 655 & 2 \\
Non-fluorescent group VI & 376 & 11 \\
Non-fluorescent group VII & 90 & 3 \\
Non-fluorescent group VIII & 338 & 11 \\
Any & 3166 & 100 \\
\hline
\end{tabular}

\section{Discussion}

Properties such as lipophilia, lipase production, and urease activity have been cited as more suitable than other characteristics for use in a grouping scheme for cutaneous diphtheroids, because they may reflect the activity of the organisms in vivo (Marples, 1969). Fatty acids are common substances on 
the skin, being the major constituents of sebum; and it is known that many corynebacteria will break down the lipids of the skin (Reisner et al., 1968; Smith and Willett, 1968). The growth of some of these organisms may be stimulated by these substances (Marples, 1969). However, for the strains used to produce this grouping scheme, the commonest site of growth of the lipophilic diphtheroids was the anterior nares; and even if strains from the nose are excluded, only 3 per cent. of the remaining lipophilic strains were isolated from the forehead, a site that has one of the highest concentrations of lipids on the body surface. The axillae, groins, and toe-webs were the commonest skin sites for yielding lipophilic diphtheroids. Lipolytic diphtheroids did not show a strong preference for any skin area but were most common in the groin and least common in the nose. Thus it is difficult to assert that lipophilia as determined in the laboratory necessarily reflects in-vivo activity.

Marples (1969) states that biochemical tests on diphtheroids are not valid unless made in parallel in media with an oleate supplement. However, good growths of the test strains occurred during the 7-day incubation period on the media used in the tests; because the growth of nearly 20 per cent. of the diphtheroids tested was in fact suppressed by Tween, this was not routinely added to the media. Consistent results were obtained on repeated testing of the same organisms by these methods, and the aim of this study was to keep the range of tests as simple as possible.

As might be expected, the properties of the nasal isolates differed from those on the skin; 88 per cent. of the isolates reduced nitrates - a similar high incidence of nitrate reducers was found in the nose by Evans (1968)-and 69 per cent. of the strains showed lipophilia in vitro. Intertriginous areas similarly yielded characteristic groups of fluorescent and non-fluorescent diphtheroids, and there were indications that other groups occur more commonly on the areas carrying sebaceous follicles and on the general skin surface. With this scheme it was possible to classify over 3000 strains of coryneform bacteria isolated from healthy and affected skin. The scheme may ultimately prove not to reflect fundamental differences between strains, but it is a workable system for the classification of cutaneous diphtheroids and appears to yield ecologically meaningful results.

\section{SUMMARY}

More than 1500 strains of aerobic cutaneous diphtheroids were characterised by morphological, biochemical, and nutritional tests. From the results of nine tests-lipophilic character, lipolytic ability, production of porphyrin, reduction of nitrate, and ability to decompose glucose, maltose, sucrose, fructose, and galactose-these strains could be divided into 15 groups: seven for the fluorescent strains and eight for the non-fluorescent strains. Distribution of the groups over the body surface varied, non-fluorescent group-I strains being particularly common in the nostrils.

I am grateful to Dr W. C. Noble for much helpful discussion. This study was supported by a grant from the Medical Research Council. 


\section{REFERENCES}

Breed, R. S., MurRay, E. G. D., AND SMITH, N. R. 1957. Bergey's Manual of determinative bacteriology, 7th ed., Baltimore, p. 578.

Cowan, S. T., AND STEEL, K. J. 1965. Manual for the identification of medical bacteria, Cambridge.

Evans, Nora M. 1968. The classification of aerobic diphtheroids from human skin. $B r$. J. Derm., 80, 81.

Harrigan, W. F., AND McCANCE, M. E. 1966. Laboratory methods in microbiology, London, p. 64.

MARPLES, M. J. 1965. The ecology of the human skin, Springfield.

MARPLES, R. R. 1969. Diphtheroids of normal human skin. Br. J. Derm., 81, Suppl. 1, 47.

MARPles, R. R., AND Williamson, P. 1969. Effects of systemic demethylchlortetracycline on human cutaneous microflora. Appl. Microbiol., 18, 228.

McBride, Mollie E., Montes, L. F., And Knox, J. M. 1970. The characterization of fluorescent skin diphtheroids. Can. J. Microbiol., 16, 941.

Puhvel, S. M., AND ReIsner, R. M. 1970. Effect of fatty acids on the growth of Corynebacterium acnes in vitro. J. Invest. Derm., 54, 48.

Reisner, R. M., Silver, D. Z., Puhvel, M., AND Sternberg, T. H. 1968. Lipolytic activity of Corynebacterium acnes. J. Invest. Derm., 51, 190.

SMITH, R. F. 1969a. Characterization of human cutaneous lipophilic diphtheroids. $J$. Gen. Microbiol., 55, 433.

SMITH, R. F. 1969b. A medium for the study of the ecology of human cutaneous diphtheroids. J. Gen. Microbiol., 57, 411.

SMITH, R. F., AND WILleTt, N. P. 1968. Lipolytic activity of human cutaneous bacteria. J. Gen. Microbiol., 52, 441.

SOMERVILLE, DoRothY A. 1969. The normal flora of the skin in different age groups. $B r$. J. Derm., 81, 248.

SOMERVille, Dorothy A. 1970. Erythrasma in normal young adults. J. Med. Microbiol., $3,57$.

Somerville, Dorothy A. 1972. A quantitative study of erythrasma lesions. Br. J. Derm., $87,130$.

Somerville, Dorothy A., Seville, R. H., Cunningham, R. C., Noble, W. C., and Savin, J. A. 1970. Erythrasma in a hospital for the mentally subnormal. Br. J. Derm., 82, 355. 